\title{
Anodic Passivation Films on Iron
}

\author{
Norio Sato \\ Electrochemistry Laboratory, Faculty of Engineering, \\ Hokkaido University*
}

\begin{abstract}
Recent work on the structure and composition of the anodic oxide film on iron is reviewed. Experiments employing ellipsometry and cathodic reduction techniques show that the passive oxide film formed in neutral solutions is composed of two different layers, an inner layer adjoining to the metal and an outer layer in contact with the solution. Ellipsometric analyses indicate that the refractive index is 3.0-0.5 $i$ for the inner layer and 1.8-0.1 $i$ for the outer layer. Chemical analyses conducted during cathodic reduction of the film reveals that there is no detectable amount of ferrous ion, $\mathrm{Fe}(\mathrm{II})$ in the inner layer as well as in the outer layer. Thermogravimetric experiments show that the anodic oxide film contains some amount of water probably concentrated in the outer layer. It is also shown that the inner layer thickness increases linearly with the anodic potential, whereas the outer layer thickness is almost independent of the potential. A practical model of the film is proposed in which the inner layer is a ferric oxide, probably $\gamma-\mathrm{Fe}_{2} \mathrm{O}_{3}$, containing a very little amount of water and the outer layer is a ferric hydroxide. The solution environment has direct effects on the outer layer which disappears in acidic solutions, but has almost no effect on the inner layer which depends only on the overpotential of anodic oxide formation.
\end{abstract}

\section{Introduction}

Iron readily dissolves in acid solution when it is made the anode. On increasing the anodic polarization, however, iron often passivates and the dissolution rate abruptly becomes to be neglected. The phenomenon of anodic passivation of iron was noted over a hundred years ago by Schönbein. ${ }^{11}$ Since then, investigations have been continued by many workers to clarify the nature of passivity. In the early days, Faraday ${ }^{2)}$ suggested that passivation might be a result of formation of a superficial film on iron. The first, direct evidence for such a film, however, was discovered much later in 1930 by Tronstad, ${ }^{3)}$ who initiated optical examination of the passivity by means of the reflection of polarized light, presently called ellipsometry. Shortly thereafter, upon introduction of electronic potentiostats, Bonfoeffer and Franck ${ }^{4}$ measured for the first time the potentiostatic-anodic polarization curve of iron in acid solution and demonstrated the critical passivation potential beyond which a marked decrease of the stationary dissolution current occurs.

Recently, the optical method of ellipsometry has been much improved and the combination of this method with refined electrochemical and chemical techniques has proved of great use in the study of

* Nishi 8-chome, Kita 13-jyo, Kita-ku, Sapporo, 060, Japan metallic passivity.

This article describes the recent progress in the anodic passivity of iron that has been investigated by ellipsometry, coulometry and chemical analysis.

\section{Anodic Oxidation of Iron}

Anodic passivation can be performed either at constant electrode potential or at constant polarization current, but potentiostatic oxidation is advantageous in that the steady state polarization curve can be obtained in a wide range of potential. Figure 1 shows the potentiostatic-anodic polariza. tion curve of iron in $1 \mathrm{~N} \mathrm{H}_{2} \mathrm{SO}_{4}$, and illustrates the potential regions of activity, incomplete passivity, passivity and transpassivity. Iron dissolution as $\mathrm{Fe}^{2+}$ ion takes place in the active dissolution potential region. Incomplete passivity appears with oscillation of the anodic current, and the passivation potential may be estimated somewhere in the potential region of incomplete passivity. In the complete passivity region the potential-independent, passivity-maintaining current is much less than the active dissolution current and carries $\mathrm{Fe}^{3+}$ ions from the iron anode to the solution. In the transpassivity region both oxygen evolution and potential-dependent iron dissolution takes place. $^{5)}$

The passivation potential is close to the so-called Flade potential, ${ }^{6)}$ an arrest potential where the 


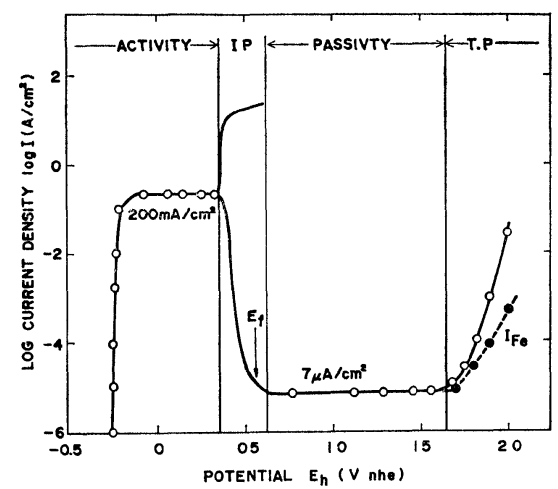

Fig. 1. Potentiostatic-anodic polarization curve of iron in $1 \mathrm{~N} \mathrm{H}_{2} \mathrm{SO}_{4}$ at $25^{\circ} \mathrm{C} .4,5$ )

$I_{\mathrm{Fe}}$ is the iron dissolution current. $I=I_{\mathrm{Fe}}$ in the active and passive potential regions.

potential decay of passivated iron during spontaneous activation is interrupted. The Flade potential has been measured as a function of solution $\mathrm{pH}$ and given by

$$
E_{f}=+0.58-0.059 \mathrm{pH}(\mathrm{V} \text { nhe })
$$

in a $\mathrm{pH}$ range from 0 to 5 at $25^{\circ} \mathrm{C}^{4)}$ Bonhoeffer and Vetter ${ }^{6)}$ described the Flade potential as a formation and reduction potential of the passive oxide film on iron. No iron oxide, however, can be found which corresponds with the Flade potential in terms of the equilibrium potential of its formation from iron and water. Göhr and Lange ${ }^{7)}$ and Vetter ${ }^{8)}$ then assumed the Flade potential as the equilibrium potential of transition from magnetite to $\gamma$-ferric oxide,

$$
2 \mathrm{Fe}_{3} \mathrm{O}_{4}+\mathrm{H}_{2} \mathrm{O}=3 \gamma-\mathrm{Fe}_{2} \mathrm{O}_{3}+2 \mathrm{H}^{+}+2 \mathrm{e},
$$

and proposed a bi-layer model consisting of an inner $\mathrm{Fe}_{3} \mathrm{O}_{4}$ layer and an outer $\gamma-\mathrm{Fe}_{2} \mathrm{O}_{3}$ layer for the passive oxide film.

Recently, Wagner" has ascribed the passivity of iron to a thin film of iron-difficient magnetite with the limiting compositions $\mathrm{Fe}_{3} \mathrm{O}_{4}$ and $\mathrm{Fe}_{2.67} \mathrm{O}_{4}$ $\left(\gamma-\mathrm{Fe}_{2} \mathrm{O}_{3}\right)$ and interpreted the Flade potential as the potential at which the composition of the oxide approaches the formula $\mathrm{Fe}_{2.83} \mathrm{O}_{4}$, half-way between the two limiting compositions. Thermodynamic calculation shows that the iron deficit $\Delta$ in $\mathrm{Fe}_{3-4} \mathrm{O}_{4}$ at $\mathrm{pH}=0$ changes from $\Delta=\mathrm{O}\left(\mathrm{Fe}_{3} \mathrm{O}_{4}\right)$ to $\Delta=1 / 3$ $\left(\mathrm{Fe}_{2.67} \mathrm{O}_{4}\right)$ in a relatively narrow potential region from $+0.5 \mathrm{~V}$ to $+0.7 \mathrm{~V}$ in accordance with the passivation potential and hence with the Flade potential.

In a de-aerated neutral borate buffer solution, as is shown in Figure 2, the anodic passivation ap-

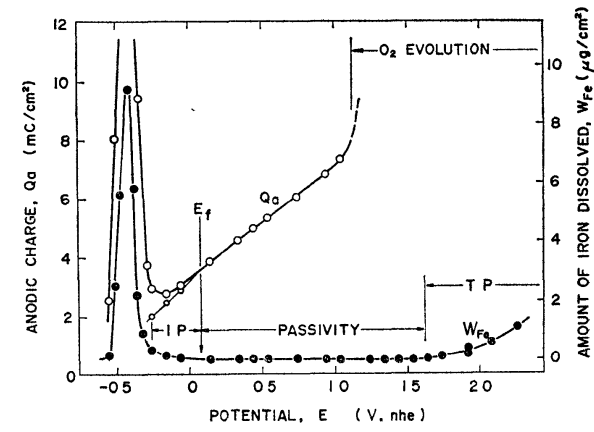

Fig. 2. Potentiostatic-anodic polarization of iron in a de-aerated borate buffer solution at $\mathrm{pH}$ 8.42(10): $Q_{a}$ is the amount of charge passed and $W_{F e}$ the amount of iron dissolved during one-hour oxidation.

pears to occur at potentials faily more negative than the Flade potential given by Equation (1). There is however some amount of $\mathrm{Fe}^{2+}$ ion dissolved from the iron anode into the solution in a potential region between the apparent passivation potential and the Flade potential. Therefore, this potential region may be assigned to the incomplete passivity. In the complete passivity region no iron dissolution takes place. The transpassivation of iron in neutral solutions begins to occur at a critical potential which is more positive than the oxygen evolution potential and almost independent of solution $\mathrm{pH}$.

It was demonstrated by Nagayama and Cohen ${ }^{11}$ that the galvanostatic-cathodic reduction of passivated iron in a neutral solution at $\mathrm{pH}=8.4$ exhibited two waves in the potential decay curve. These two potential waves were then attributed to an outer " $\gamma-\mathrm{Fe}_{2} \mathrm{O}_{3}$ " layer in contact with the solution and an inner " $\mathrm{Fe}_{3} \mathrm{O}_{4}$ " layer in contact with the iron. Recently, however, Sato, Kudo and Noda ${ }^{12 !}$ have shown that the passive oxide film contains no magnetite layer but consists of anhydrous and hydrous ferric oxides.

\section{Ellipsometry}

Ellipsometry is an optical technique which uses the change in the polarization of light that occurs on reflection from the metal surface to determine the optical parameter of the metal or, if a surface film is present, the thickness and optical properties of the layer. The component layout of an ellipsometer is shown in Figure 3, and the cell in Figure 4.

The change in the polarization of light upon reflection can be defined from the optics by the rela- 


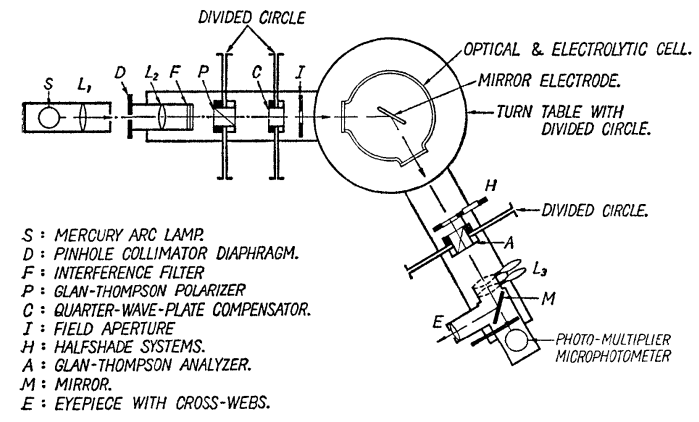

Fig. 3. Component layout of ellipsometer.

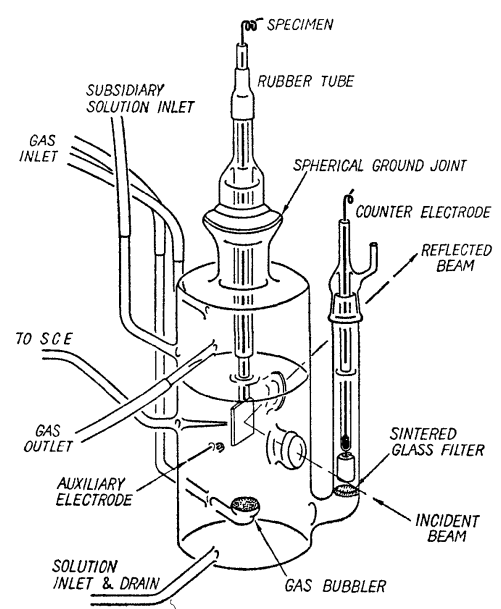

Fig. 4. Electrolytic cell for in situ ellipsometry.

tive complex reflection cofficient $\rho$;

$$
\rho=\tan \phi \exp (i \Delta),
$$

where $\tan \phi$ is the relative amplitude attenuation and $\Delta$ the relative phase retardation between the two vibration directions of light, parallel and perpendicular to the incident plane. By use of an ellipsometer we can measure $\Delta$ and $\phi$ with the azimuthal angles, $P$ and $A$, of the polarizer and analyzer so adjusted that the resultant light may be totally extinguished. In the simple case where the compensator has the fast axis fixed at $45^{\circ}$ to the incident plane and gives the phase retardation exactly equal to a quarter wave between the two vibration directions, $P$ and $A$ are related to $\Delta$ and $\phi$ as follows.

$$
\begin{aligned}
& \Delta=2 P+90^{\circ}, \\
& \phi=A,
\end{aligned}
$$

General equations relating $P$ and $A$ with $\Delta$ and $\phi$ are more complicated than Equation (4).

For a film-free surface of a metal immersed in a solution of known refractive index, the optics theory gives $Q$ as a function of $N_{m}$, the complex refrac- tive index of the metal, $\phi$ the angle of incidence, and $\lambda$, the wave length of light,

$$
\rho=\tan \phi \exp (i \Delta)=f\left(N_{m}, \phi, \lambda\right)
$$

At constant $\phi$ and $\lambda, \rho$ is a function of only $N_{m}=$ $n_{m}+i k_{m}$, where the real part $n_{m}$ is usually called the refractive index and the imaginary part $k_{m}$ the extinction index. It is, therefore, straightforward to estimate two unknown $n_{m}$ and $k_{m}$ from two measurable parameters $\Delta$ and $\phi$.

A film free surface of iron can be obtained by cathodic reduction of the electropolished iron surface in a de-aerated borate buffer solution at $\mathrm{pH}$ 8.42. ${ }^{11,12)}$ The refractive index $N_{m}$ of iron measured by ellipsometry of the cathodically reduced iron surface at an incidence angle of $73^{\circ} 16^{\prime}$ is given by

$$
N_{m}=(3.52 \pm 0.08)-(3.54 \pm 0.10) i
$$

Table 1 shows the refractive index values of iron measured by different workers.

If the metal is covered with a film, $\rho$ is then given instead of Equation (5) as,

$$
\rho=\tan \phi \exp (i \Delta)=f\left(N_{m}, N_{f}, L, \phi, \lambda\right)
$$

where $N_{f}$ is the complex refractive index of the film and $L$ the film thickness. At constant $\phi$ and $\lambda, \rho$ is now a function of $N_{f}=n_{f}-i k_{f}$ and $L$, provided that $N_{m}$ is known. Then, Equation (7) contains three unknowns $n_{f}, k_{f}$ and $L$, and it is theoretically impossible to estimated these three unknowns from a single pair of measurable parameters $\Delta$ and $\phi$. However, estimation of these unknowns may be made in such a way that a number of pairs of measured $P$ - $A$ values for various film thicknesses are fitted to the theoretical $P-A$ locus of a growing or reducing layer of index $n_{f}-i k_{f}$. In other words, the index and the film thickness may be estimated by comparing the experimental $P-A$ curve with a number of theoretically computed $P-A$ loci of growing or reducing layers of different indices. In this procedure it is necessary to limit $L, n_{f}$ and $k_{f}$ each in a relatively narrow range which can be pre-estimated for $n_{f}$ and $k_{f}$ if the approximate composition of the film is known and for $L$ by using other methods such as coulometry and impedance measurements.

Figure 5 shows the change in $P$ and $A$ at an incident angle of $59^{\circ} 25^{\prime}$ during the one-hour oxidation of iron at a passivity potential and the following galvanostatic reduction of the anodic film in a de-aerated borate buffer solution at $\mathrm{pH} 8.42$. We see that at the end of the oxidation-reduction cycle both $P$ and $A$ return to their original values cor- 
Table 1. Optical constants of iron for wavelength $5461 \AA$.

\begin{tabular}{|c|c|c|}
\hline \multirow{2}{*}{\multicolumn{2}{|c|}{$\begin{array}{l}2.29-3.29 i^{*} \\
2.19-3.19 i^{*}\end{array}$}} & Minor (1903) ${ }^{14)}$ \\
\hline & & Bernoulli $(1909)^{15)}$ \\
\hline \multicolumn{2}{|l|}{$2.34-3.17 i^{*}$} & Tool $(1910)^{16)}$ \\
\hline \multicolumn{2}{|l|}{$2.7-2.7 i$} & Leberknight \& Lustman (1939) ${ }^{17}$ \\
\hline $3.06-3.67 i$ & $\Phi=60^{\circ}$ & Winterbottom $(1950)^{18}$ \\
\hline $2.75-3.65 i$ & $45^{\circ}$ & Winterbottom $(1955)^{19 !}$ \\
\hline $2.98-3.99 i$ & $60^{\circ}$ & Winterbottom $(1955)^{19 !}$ \\
\hline $2.78-3.87 i$ & $75^{\circ}$ & Winterbottom (1955) ${ }^{19}$ \\
\hline $3.23-3.84 i$ & $70^{\circ}$ & Menzel \& Gebhart (1962) ${ }^{201}$ \\
\hline $3.35-3.84 i^{\dagger}$ & $66^{\circ}$ & Yolken \& Kruger (1965) ${ }^{21)}$ \\
\hline $3.50-3.66 i^{\dagger}$ & $60^{\circ}$ & Ord \& DeSmet $(1966)^{22)}$ \\
\hline $3.18-3.85 i^{\dagger}$ & $59^{\circ} 25^{\prime}$ & Kudo, Sato \& Okamoto $(1968)^{10)}$ \\
\hline $3.21-3.79 i^{\dagger}$ & & McBee \& Kruger (1969) ${ }^{231}$ \\
\hline $3.24-3.98 i^{\dagger}$ & $68^{\circ} 05^{\prime}$ & Bockris, et al. $(1971)^{24)}$ \\
\hline $3.52-3.54 i^{\dagger}$ & $73^{\circ} 16^{\prime}$ & Sato \& Noda $(1972)^{25)}$ \\
\hline
\end{tabular}

* Interpolated, $\Phi=$ Angle of incidence.

$\dagger$ Electrochemically reduced surfaces in solution.

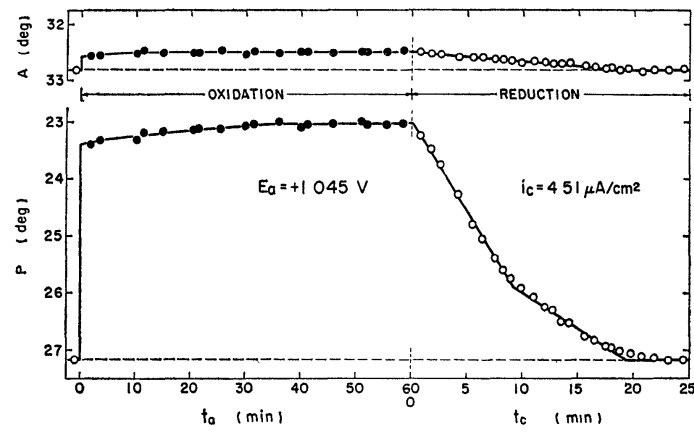

Fig. 5. Change in ellipsometric parameters $P$ and $A$ during potentiostatic oxidation and galvanostatic reduction of iron in borate buffer solution at $\mathrm{pH} 8.42\left(25^{\circ} \mathrm{C}\right) .^{101}$ Incident angle $\phi=59^{\circ} 25^{\prime}$.

responding to the bare surface of iron. Such reproduction of the original iron surface is never observed when the oxidation is made in the active potential region probably because of surface roughening. ${ }^{10)}$

\section{Cathodic Reduction of Passive Oxide Film}

As we have seen in Figure 5, the anodic film can be removed by cathodic current. During the cathodic reduction, the film dissolves cathodically in the solution as $\mathrm{Fe}^{2+}$ ion; $;^{11,12)}$

$$
\mathrm{Fe}_{2} \mathrm{O}_{3}+6 \mathrm{H}^{+}+2 \mathrm{e} \longrightarrow 2 \mathrm{Fe}^{2+}+3 \mathrm{H}_{2} \mathrm{O}
$$

Figure 6 gives the change in the amount of $\mathrm{Fe}^{2+}$ ion dissolved and the change in $P$ during galvanostatic cathodic reduction of the film in a deaerated borate buffer solution at $\mathrm{pH} 8.42$. In this solution, as shown in Figure 6, the current ef-

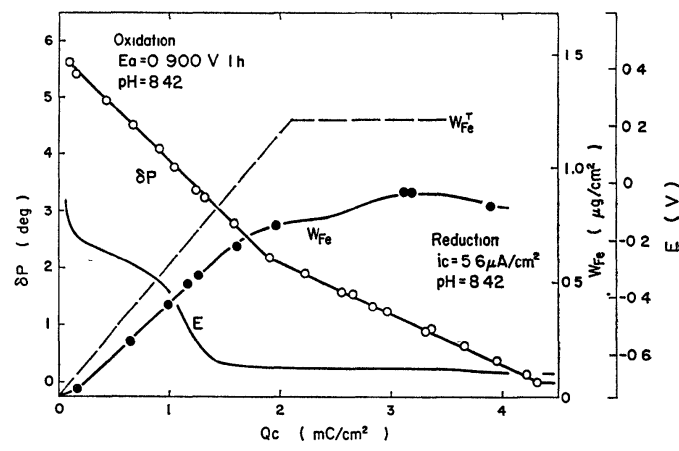

Fig. 6. Amount of iron dissolved cathodically from the film, potential, and ellipsometric parameter $\boldsymbol{P}$ as functions of cathodic charge passed during galvanostaticcathodic reduction in a borate buffer solution at $\mathrm{pH} 8.42\left(25^{\circ} \mathrm{C}\right)^{12,25)}$ : Incident angle $\phi=73^{\circ} 16^{\prime}$. The film was formed at $\mathrm{pH} 8.42$ and reduced at $\mathrm{pH} 8.42$.

ficiency for the cathodic reduction of the film is not $100 \%$ but about $80 \%$. It is this solution in which Nagayama and Cohen ${ }^{11}$ carried out cathodic reduction experiments to analyze the film composition: Recently, Ho and $\mathrm{Ord}^{13}$ ) also used this solution for ellipsometric measurements during the cathodic reduction of the film. Further experiments made by Sato, Kudo and Noda ${ }^{12}$ have shown that the current efficiency for the cathodic reduction of the film increases with decreasing solution $\mathrm{pH}$, reaches at $100 \%$ at $\mathrm{pH} 6.5$, and remains at $100 \%$ in the $\mathrm{pH}$ range between $\mathrm{pH} 6.5$ and $\mathrm{pH} 4$.

Figure 7 gives the cathodic reduction curve obtained in a borate buffer solution at $\mathrm{pH} 6.35$ for the anodic oxide film formed at $\mathrm{pH}$ 8.42. The 


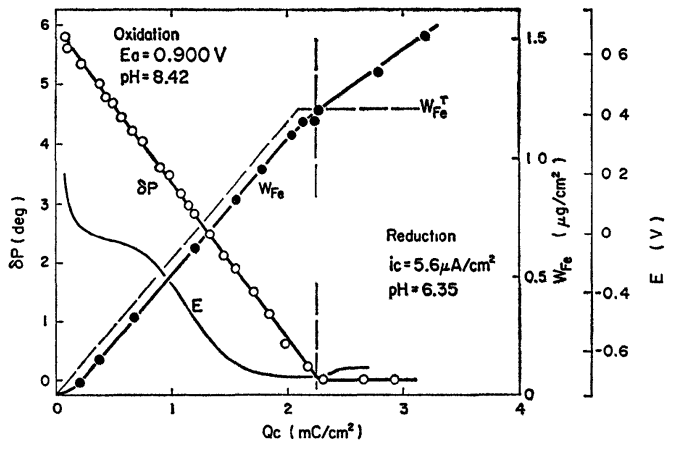

Fig. 7. Amount of iron cathodically dissolved from the film, potential, and ellipsometric parameter $P$ as functions of cathodic charge passed during galvanostatic-cathodic reduction in a borate buffer solution at $\mathrm{pH} 6.35\left(25^{\circ} \mathrm{C}\right) .{ }^{25)} \quad$ Incident angle $\phi=$ $73^{\circ} 16^{\prime}$. The film was formed at $\mathrm{pH} 8.42$ and reduced at $\mathrm{pH} 6.35$.

amount of $\mathrm{Fe}^{2+}$ ion, $W_{\mathrm{Fe}}$, coming from the film increases linearly with the cathodic charge $Q_{c}$ passed, and the current efficiency estimated from $d W_{\mathrm{Fe}} / d Q_{c}$ is $100 \%$ until the whole film is reduced. In this solution, however, $W_{\mathrm{Fe}}$ continues to increase even after complete reduction of the film because of dissolution of the iron substrate from the bare surface.

We see in Figure 7 that, at the end of film reduction at which $\delta P=0$, the measured amount of $W_{\mathrm{Fe}}$ is equal to the theoretical amount $W_{\mathrm{Fe}}^{T}$ of iron in ferric oxide which is calculated from the film charge $Q_{f}$ measured in anodic formation of the film: $W_{\mathrm{Fe}}^{T}=55.85 Q_{f} / 3 F=0.1925 Q_{f} \mathrm{~g} / \mathrm{mC}$. It is this agreement between $W_{\mathrm{Fe}}^{\max }$ and $W_{\mathrm{Fe}}^{T}$ from which we can prove that almost all the iron ions in the film are in the form of $\mathrm{Fe}^{3+}$. Suggestions have been made by different workers ${ }^{7,8,11,13}$, that the anodic oxide film on iron consists of an inner magnetite jayer and an outer ferric oxide layer, but, as described above, it is now revealed that the film contains no or very little, if any, $\mathrm{Fe}^{2+}$ ions.

In order to make use of cathodic reduction as a method of analyzing the film, the iron dissolution from the bare suface that occurs after the film reduction in solution at $\mathrm{pH} 6.35$ must be inhibited. To accomplish this, we can add $\mathrm{As}_{2} \mathrm{O}_{3}$ as an inhibitor in the borate buffer solution of $\mathrm{pH}$ 6.35 and obtain the cathodic reduction curve shown in Figure 8. We see that this solution inhibits the iron dissolution from the bare surface and hence can be used for cathodic reduction to analyze the amount of iron in the film.

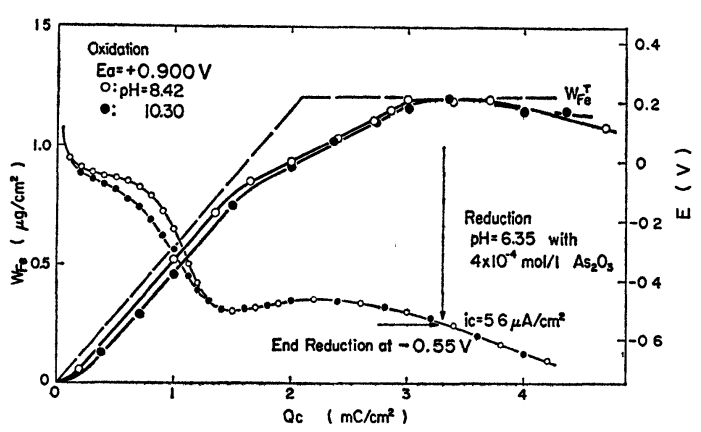

Fig. 8. Cathodic reduction of anodic oxide film in a borate buffer solution at $\mathrm{pH} 6.35$ $\left(25^{\circ} \mathrm{C}\right.$ ) containing $4 \times 10^{-4} \mathrm{~mol} / l \mathrm{As}_{2} \mathrm{O}_{3}$ as inhibitor ${ }^{12)}$ : The film was formed at $\mathrm{pH}$ 8.42 and 10.30 and reduced at $\mathrm{pH} 6.35$.

The reccommended procedures are as follows:

(1) Use $0.15 \mathrm{~N}$ borate buffer solution at $\mathrm{pH} 6.35$ containing $4 \times 10^{-4} \mathrm{~mol} / l \mathrm{As}_{2} \mathrm{O}_{3}$.

(2) Apply a constant cathodic current of $5.6 \mu \mathrm{A} /$ $\mathrm{cm}^{2}$ to reduce the anodic oxide film in the above solution free from dissolved oxygen, and measure the potential with the lapse of time.

(3) Stop the cathodic reduction when the potential reaches the reduction potential, $-0.55 \mathrm{~V}(\mathrm{nhe})$, as indicated in Figure 8, and immediately take the solution out of the cell for determination of its iron content by chemical analysis.

As shown in Figure 8, $W_{\mathrm{Fe}}^{\max }$ thus obtained by the above method is in good agreement with $W_{\mathrm{Fe}}^{T}$, the theoretically expected amount of iron from the film charge $Q_{f}$,

$$
W_{\mathrm{Fe}}^{\max }=W_{\mathrm{Fe}}^{T}=0.1929 Q_{f} \mu \mathrm{g} / \mathrm{mC} .
$$

Since this is based on trivalent iron ions, as mentioned before, the anodic film is here again found to be ferric oxide or hydroxide.

\section{Layer Structure and Composition of Passiva- tion Film}

We have seen in Figure 7 that anodic oxide films can be dissolved by galvanostatic-cathodic reduction in a de-aerated borate buffer solution at $\mathrm{pH}$ 6.35 (containing no inhibitor). During the cathodic reduction the reaction given by Equation (8) proceeds at $100 \%$ current-efficiency and no other simultaneous reaction that might cause the film to change in quality occurs.

The change in ellipsometric parameters $P$ and $A$ during the cathodic reduction of the film in this solution is represented in Figure 9. A break is seen to occur in the $P-A$ curve. This is an evidence 
Table 2. Optical constants of iron oxides for wavelength $5461 \AA$.

Magnetite, cubic

$2.58-0.28 i$

$2.5-0.3 i$

$2.39-0.249 i$

Hematite rhombohedral

$$
\begin{aligned}
& 3.20-0.97 i^{*} \\
& 3.46-1.07 i \\
& 2.88-0.378 i
\end{aligned}
$$

Hydrated ferric oxide, amorphous

$$
\begin{aligned}
& 2.5-0.0 i \\
& (2.0<n<2.5, k<0.1) \\
& 1.87
\end{aligned}
$$

Anodic oxide film

$2.6-0.4 i$

$2.55-0.35 i$

$2.48-0.273 i$

$(2.7 \pm 0.1)-(0.13 \pm 0.05) i$

Inner layer of anodic oxide film

$$
(3.0 \pm 0.1)-(0.5 \pm 0.1) i
$$

Outer layer of anodic oxide film $(1.8 \pm 0.1)-(0.1 \pm 0.05) i$

\author{
Leberknight \& Lustman (1939) ${ }^{17}$ \\ Winterbottom (1950) ${ }^{18}$ \\ Bockris, et al. (1971) 24 \\ Leberknight \& Lustman (1939) ${ }^{17}$ ) \\ Winterbottom (1950) ${ }^{18}$ \\ Bockris, et al. (1971) ${ }^{24)}$ \\ Winterbottom (1950) \\ Kodama (1972) ${ }^{26)}$ \\ Ord \& DeSmet (1966) ${ }^{22)}$ \\ Kudo, Sato \& Okamoto (1968) ${ }^{10)}$ \\ Goswami \& Staehle (1971) ${ }^{27 !}$ \\ Bockris, et al. (1971) ${ }^{24)}$ \\ Sato \& Noda (1972) 25 \\ Sato \& Noda (1972) ${ }^{25}$
}

* Calculated.

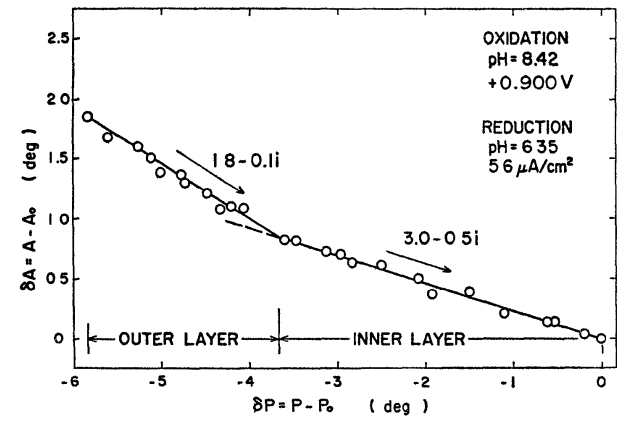

Fig. 9. Change in $P$ and $A$ during galvanostaticcathodic reduction of the film in a borate buffer solution at $\mathrm{pH} 6.35\left(25^{\circ} \mathrm{C}\right) .^{251}$ Incident angle $\phi=73^{\circ} 16^{\prime}$. The film was formed at $\mathrm{pH} 8.42$ and reduced at $\mathrm{pH} 6.35$ in absence of inhibitor.

indicating that the film consists of two layers with different refractive indices. Computer calculation for the range of the refrative index from $n_{f}=1.5$ to $n_{f}=3.5$ and from $k_{f}=0.0$ to $k_{f}=1.0$, within which all the refractive indices of iron oxides are found (Table 2), gives the best fit between the data on film reduction in Figure 9 and a theoretical curve for the removal of $30 \AA$ of an outer layer with the refractive index,

$$
{ }_{\mathrm{II}} N_{f}=(1.8 \pm 0.1)-(0.1 \pm 0.05) i,
$$

followed by the removal of $23.5 \AA$ of an inner layer

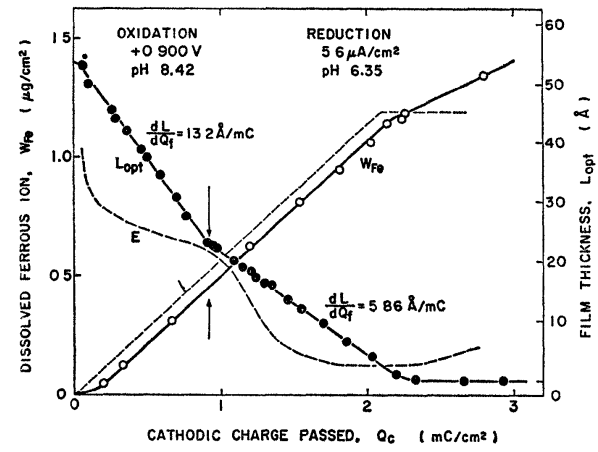

Fig. 10. Change in film thickness and amount of iron dissolved from the film during galvanostatic cathodic reduction in a borate buffer solution at $\mathrm{pH} 6.35\left(25^{\circ} \mathrm{C}\right) . .^{251}$ The film was formed at $\mathrm{pH} 8.42$ and reduced at $\mathrm{pH} 6.35$.

with the refractive index,

$$
{ }_{\mathrm{I}} N_{f}=(3.0 \pm 0.1)-(0.5 \pm 0.1) i .
$$

Figure 10 gives the thickness reduction curve and the film dissolution curve during the cathodic reduction at $\mathrm{pH}$ 6.35, and Figure 11 shows the relation between the film thickness $L$ and the amount of iron ion dissolution $W_{\mathrm{Fe}}$ from the film. It is seen that the iron density in the two layers is different; $32.9 \mathrm{ng} / \AA \mathrm{cm}^{2}$ for the inner layer and 14.6 $\mathrm{ng} / \AA \mathrm{cm}^{2}$ for the outer layer. In terms of the iron 
Table 3. Density, $\rho$, and iron ion density, $W_{\mathrm{Fe}} / L$, calculated from the lattice constants of iron oxides and hydroxides.

\begin{tabular}{|c|c|c|c|}
\hline Compound & $\begin{array}{c}\text { Cell Constant } \\
(\AA)\end{array}$ & $\begin{array}{c}\rho \\
\left(\mathrm{g} / \mathrm{cm}^{3}\right)\end{array}$ & $\begin{array}{c}W \mathrm{Fe}_{\mathrm{e}} / L \\
\left(\mathrm{ng} / \mathrm{A} \cdot \mathrm{cm}^{2}\right)\end{array}$ \\
\hline$\gamma-\mathrm{Fe}_{2} \mathrm{O}_{3}$ & $\begin{array}{l}8.30^{291} \\
-8.34\end{array}$ & & . \\
\hline $\begin{array}{l}\square{ }_{8} \mathrm{H}_{0} \mathrm{Fe}_{64} \mathrm{O}_{96}{ }^{28)} \\
\square{ }_{0} \mathrm{H}_{12} \mathrm{Fe}_{60} \mathrm{O}_{96}\end{array}$ & & $\begin{array}{l}4.91 \pm 0.4 \\
4.71 \pm 0.4\end{array}$ & $\begin{array}{l}34.3 \pm 2.3 \\
32.3 \pm 2.0\end{array}$ \\
\hline$\alpha-\mathrm{Fe}_{2} \mathrm{O}_{3}$ & & $5.24^{301}$ & 37.1 \\
\hline $\mathrm{Fe}_{3} \mathrm{O}_{4}$ & $8.397^{311}$ & 5.20 & 37.6 \\
\hline$\gamma-\mathrm{FeOOH}$ & $\begin{array}{l}\left.a=3.06^{32}\right) \\
b=12.4 \\
c=3.87\end{array}$ & 4.01 & 25.2 \\
\hline $\mathrm{Fe}_{2} \mathrm{O}_{3} \cdot 1.8 \mathrm{H}_{2} \mathrm{O}$ & $\begin{array}{l}a=5.08^{331} \\
b=9.4\end{array}$ & 3.29 & 19.1 \\
\hline $\begin{array}{l}\text { Inner layer* } \\
\text { Outer layer* }\end{array}$ & $\begin{array}{l}\text { Measured } \\
\text { Measured }\end{array}$ & & $\begin{array}{l}32.9 \pm 0.8^{25} \\
14.6 \pm 1.2\end{array}$ \\
\hline
\end{tabular}

* Thickness-charge ratio, $L / Q$, is $5.86 \pm 0.2\left(\AA \cdot \mathrm{cm}^{2} / \mathrm{mC}\right)$ for the inner layer and $13.2 \pm 1.2\left(\AA \cdot \mathrm{cm}^{2} / \mathrm{mC}\right)$ for the outer layer.

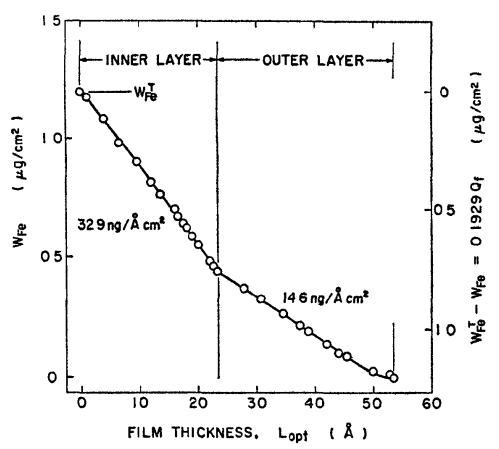

Fig. 11. Relation between ellipsometric thickness $L$ and amount of iron in the film $W_{\mathrm{Fe}^{-}}^{T}$ $W_{\mathrm{Fe}}$ : Data are based on the result shown in Figure 10.

density in the layer, as shown in Table 3, the inner layer agrees well with $\gamma-\mathrm{Fe}_{2} \mathrm{O}_{3}$, which may contain water to the limit $\mathrm{Fe}_{2} \mathrm{O}_{3} \cdot 0.2 \mathrm{H}_{2} \mathrm{O}$, ${ }^{28)}$ and the outer layer appears to be a hydrous ferric oxide containing water more than $\mathrm{Fe}_{2} \mathrm{O}_{3} \cdot 1.8 \mathrm{H}_{2} \mathrm{O}$.

The presence of water in the anodic oxide film can be checked by either radiometry using tritated water or gravimetry using a high sensitivity vacuum thermomicrobalance. Figure 12 shows a thermogravimetric curve. We see that the anodic oxide film contains two kinds of water different in their bonding state, one desorbed below $120^{\circ} \mathrm{C}$ and the other removed in a temperature range from $120^{\circ} \mathrm{C}$ to $450^{\circ} \mathrm{C}$.

$$
{ }_{T} W_{\mathrm{H}_{2} \mathrm{O}}={ }_{1} W_{\mathrm{H}_{2} \mathrm{O}}+{ }_{2} W_{\mathrm{H}_{2} \mathrm{O}},
$$

where ${ }_{T} W_{\mathrm{H}_{2} \mathrm{O}}$ is the total amount of water, ${ }_{1} W_{\mathrm{H}_{2} \mathrm{O}}$ is

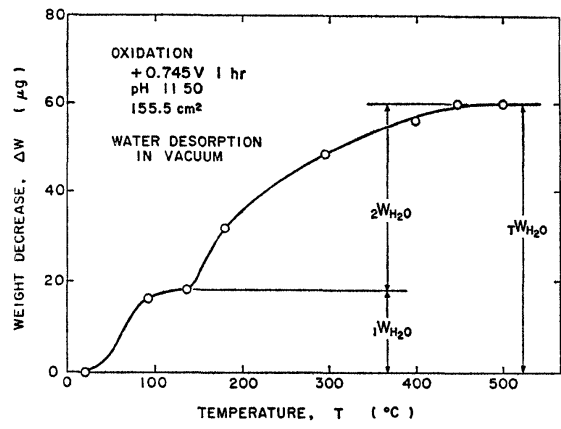

Fig. 12. Water desorption from an anodic oxide film in vacuum as a function of temperature $^{25)}$ : The film was formed in a borate solution at $\mathrm{pH} 11.50\left(25^{\circ} \mathrm{C}\right)$.

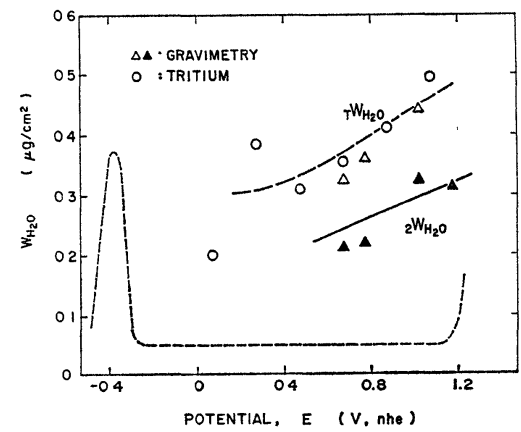

Fig. 13. Amount of water in the film formed by potentiostatic one-hour oxidation in a borate buffer solution at $\mathrm{pH} 8.42$ $\left.\left(25^{\circ} \mathrm{C}\right) .25,34\right)$ 
desorbed below $120^{\circ} \mathrm{C}$ and ${ }_{2} W_{\mathrm{H}_{2} \mathrm{O}}$ is removed above $120^{\circ} \mathrm{C}$. Figure 13 shows the content of water in the anodic film formed by the one-hour oxidation in borate buffer solution at $\mathrm{pH} 8.42$. We see that the total amount of water measured by gravimetry is in good agreement with the amount of water measured by radiometry. The average content of water in the film is estimated from ${ }_{2} W_{\mathrm{H}_{2} \mathrm{O}}$ to be $\mathrm{Fe}_{2} \mathrm{O}_{3} \cdot 1.4 \mathrm{H}_{2} \mathrm{O}$.

As mentioned above, $\gamma-\mathrm{Fe}_{2} \mathrm{O}_{3}$ may contain a small amount of water in its spinel structure to the limit of $\gamma-\mathrm{Fe}_{2} \mathrm{O} \cdot 0.2 \mathrm{H}_{2} \mathrm{O}$. ${ }^{28)}$ If we assume the inner layer to be $\gamma-\mathrm{Fe}_{2} \mathrm{O}_{3} \cdot 0.2 \mathrm{H}_{2} \mathrm{O}$, the water content in the outer layer could be estimated from the water measurements ${ }_{2} W_{\mathrm{H}_{2} \mathrm{O}}$ shown in Figure 13 and the ratio in amount of the outer layer to the total film shown in Figure 10 and 11. Thus, we have for the outer layer $\mathrm{Fe}_{2} \mathrm{O}_{3} \cdot 2.25 \mathrm{H}_{2} \mathrm{O}$ with the inner layer $\gamma-\mathrm{Fe}_{2} \mathrm{O}_{3} \cdot 0.2 \mathrm{H}_{2} \mathrm{O}$.

The thickness of two optically different layers of the anodic oxide film formed by potentiostatic onehour oxidation in a borate buffer solution at $\mathrm{pH}$ 8.42 is now shown as a function of potential in Figure 14.

The thickness estimation by ellipsometry is in principle sensitive to the refractive index values of the metal and the film. The error caused by a deviation in the index values can be calculated, and the index of iron in Equation (6) leads to an error less than $1 \%$ in the thickness range shown in Figure 14. The index in Equation (11) causes an error of $\pm 0.7 \AA$ at $25 \AA$ of the inner layer thickness, which is less than the experimental scatter of about $15 \%$ shown in Figure 14. The index in Equation (10) causes an error of $\pm 16 \AA$ at $30 \AA$ in the outer

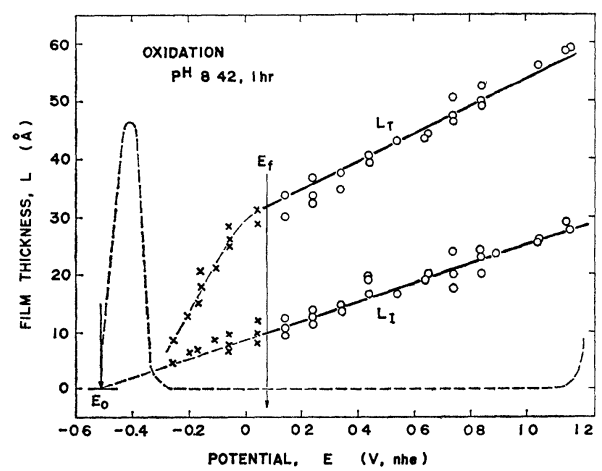

Fig. 14. Thickness of the inner and outer layers of the film formed by potentiostatic onehour oxidation in a borate buffer solution at $\mathrm{pH} 8.42\left(25^{\circ} \mathrm{C}\right)$ as a function of potential. ${ }^{25}$ ) layer thickness. Accordingly, as far as the inner layer is concerned, the thickness estimation by ellipsometry can be made sufficiently accurately.

At potentials more negative than the Flade potential an incomplete passivity film is formed which probably consists of an inner layer of $\mathrm{Fe}_{3} \mathrm{O}_{4}$ and an outer layer of ferrous and ferric hydroxides, but the refractive index of this film is not known. If we assume the refractive index close to that of the passivity film, approximate thickness estimation may be made. Thickness shown in Figure 14 for the film formed in the incomplete passivity region is thus based on the refractive index given by Equation (10) and (11).

It should be noted in Figure 14 that the intercept of the plot of the inner layer thickness against the potential, which represents the potential at zero thickness of the inner layer, is close to the equilibrium potential of the following film formation reaction

$$
\begin{aligned}
& 2 \mathrm{Fe}+6 \mathrm{H}_{2} \mathrm{O} \rightleftarrows \gamma-\mathrm{Fe}_{2} \mathrm{O}_{3}+6 \mathrm{e}, \\
& \begin{aligned}
E_{0}=-0.015-0.059 \mathrm{pH} \mathrm{V}(\mathrm{nhe}), \\
=-0.505 \mathrm{~V} \text { (nhe), at } \mathrm{pH} 8.42 .
\end{aligned}
\end{aligned}
$$

The thickness of the outer hydrous oxide layer is nearly constant and independent of the potential. It is therefore likely that almost the entire overvoltage occurs in the inner layer. The average field strength in the inner layer is then given by,

$$
(\Delta E / \Delta L)=(5.60 \pm 0.45) \times 10^{6} \mathrm{~V} / \mathrm{cm},
$$

Figure 15 gives the nearly steady state thickness of the inner and outer layers of the anodic oxide film formed at a constant overvoltage as a function of solution $\mathrm{pH}$, an overvoltage being referred to Equation (14). The outer layer is seen to depend on the solution $\mathrm{pH}$ and the anion present in the solution and it disappears in acid solutions. It is

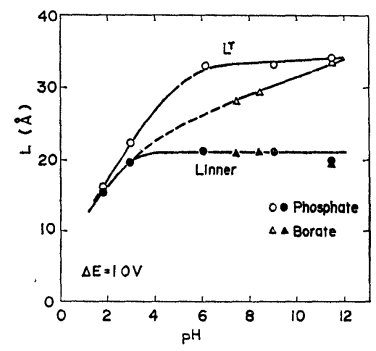

Fig. 15. Effect of solution $\mathrm{pH}$ on the thickness of the film formed by one-hour oxidation at a constant overvoltage in borate and phosphate solutions $\left(25^{\circ} \mathrm{C}\right) .^{251}$ 


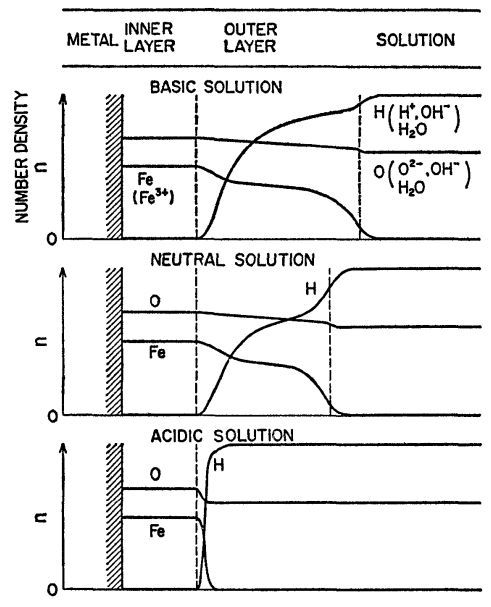

Fig. 16. Film model proposed for the passive oxide film on iron. ${ }^{25 \text { ) }}$

also apparent that the inner layer thickness does not depend on the solution $\mathrm{pH}$ in the range from $\mathrm{pH} 4$ to $\mathrm{pH} 11$. In the acidic $\mathrm{pH}$ region the inner layer thickness decreases with increasing acidity of the solution. This is due to the passivity-maintaining, film dissolution current which increases exponentially with decreasing solution $\mathrm{pH}$. Increasing dissolution rate of the film requires increasing ionic current through the film, which causes the film thickness to decrease.

It is likely from Figure 15 that the nature and composition of the inner layer is the same in a wide range of $\mathrm{pH}$. The outer layer however is much dependent on the solution environment, such as $\mathrm{pH}$ and anions, and the procedure of passivation. ${ }^{121}$

The layer structure of the anodic passivation film in acidic, neutral and alkaline solutions is illustrated in Figure 16. The inner layer, which is $\gamma$-ferric oxide, receives no influence of the solution $\mathrm{pH}$ and anion but is determined by the overvoltage of film formation. There exists a high electric field of the order of $10^{6} \mathrm{~V} / \mathrm{cm}$ in the inner layer. The outer layer undergoes environmental influence of the solution. It is the inner layer on which the iron passivity depends.

\section{Concluding Remarks}

The foregoing review is limited in scope to the composition and layer structure. There are other experiments worth noting which are not reviewed here. Among them are the electron diffraction analysis which identified the passive film as $\gamma$ $\mathrm{Fe}_{2} \mathrm{O}_{3},{ }^{11,35)}$ the nuclear microanalysis which estimated the amount of oxygen in the film, ${ }^{36)}$ and the ellipsometric measurements which roughly estimated the change in the optical constant of the film during the transition from the active state to the passive state. ${ }^{24}$

Beside the structure and composition of the film, there are other topics in the passivity of iron such as the anodic formation, growth, dissolution, local breakdown by halide ion, and semiconducting property of the passive film. All these topics are not only of academic interest in surface electrochemistry but of practical significance in corrosion and protection of iron-base structures.

It is doubtless that the recent progress in iron passivity is much indebted to the development of ellipsometric technique which is still being improved in automatic and spectrometric measurements. In spite of its limitations at present, ellipsometry is a useful technique for passivity studies and its refinement will promise the further understanding of the nature of passive oxide films.

(Received July 19, 1974)

\section{References}

1) C. Schönbein: Pogg. Ann., 37, 390, 590 (1982).

2) M. Faraday: "Experimental Researches in Electricity," Vol. II, University of London (1844).

3) L. Tronstad: Z. physik. Chem., 142-A, 241 (1929); 158, 369 (1932); Trans. Faraday Soc., 31, 1151 (1935).

4) U. F. Franck: $\quad$ Z. Naturforsch., 4a, 378 (1949); K. F. Bonhoeffer: Z. Metallkunde, 44, 77 (1953).

5) U. F. Franck \& K. Weil: Z. Elektrochem., 56, 814 (1952).

6) K. F. Bonhoeffer \& K.J. Vetter: Z. phys. Chem., 196, 127 (1950).

7) H. Göhr \& E. Lange: Naturwissenschaften, 43, 12 (1956); Z. Elektrochem. Ber. Bunsenges. phys. Chem., 61, 1292 (1957).

8) K. J. Vetter: Z. Elektrochem. Ber. Bunsenges. phys. Chem., 62, 642 (1958).

9) C. Wagner: Ber. Bunsenges. phys. Chem., 77, 1090 (1973).

10) K. Kudo, N. Sato \& G. Okamoto: Bull. Faculty of Engineering, Hokkaido University, No. 47, 141 (1968); N. Sato \& K. Kudo: Electrochim. Acta, 16, 447 (1971).

11) M. Nagayama \& M. Cohen: J. Electrochem. Soc., 109, 781 (1962).

12) N. Sato, K. Kudo \& T. Noda: Electrochim. Acta, 16, 1909 (1971).

13) F. C. Ho \& J. L. Ord: J. Electrochem. Soc., 119, 139 (1972).

14) R. S. Minor: Ann. Physik, 10, 581 (1903).

15) A. L. Bernoulli: Ann. Physik, 29, 595 (1909).

16) A. Q. Tool: Phys. Rev., 31, 1 (1910). 
17) C. E. Leberknight \& B. Lustman: J. Opt. Soc. Amer., 29, 59 (1939).

18) A. B. Winterbottom: J. Iron and Steel Inst., 165, 9 (1950).

19) A. B. Winterbottom: "Optical Studies" of Metal Surfaces," Det Kgl. Norsh Videnskab. Selskab. Strifter Nr. 1, Trondheim, K. Kommisjon. Hos. F. Bokkandal (1955).

20) E. Menzel \& J. Gebhart: Z. Phys., 168, 392 (1962).

21) H. T. Yolken \& J. Kruger: J. Opt. Amer., 55, 842 (1965).

22) J. L. Ord \& D. J. DeSmet: J. Electrochem. Soc., 113, 1258 (1966).

23) C. L. McBee \& J. Kruger: Surface Sci., 16, 340 (1969).

24) J. O'M. Bockris, M. A. Genshaw, V. Brusic \& H. Wroblowa: Electrochim. Acta, 16, 1859 (1971).

25) T. Noda, K. Kudo \& N. Sato: J. Japan Inst. Metals, 37, 951, 1088 (1973).

26) T. Kodama: Extended Abstract, p. 87; The Fifth International Congress on Metallic Corrosion, Tokyo (1972).
27) K. N. Goswami \& R.W. Staehle: Electrochim. Acta, 16, 1895 (1971).

28) M. C. Bloom \& L. Goldenberg: Corrosion Sci., 5, 623 (1965).

29) W. B. Pearson: "Lattice Spacings' and Structures of Metals," p. 1015, Pergamon Press (1958); Landolt-Börnstein, 6, Aufl., Bd. I, Teil 4, p. 135, Springer Verlag (1955).

30) "Handbook of Chemistry and Physics," Ed. by C. D. Hodgman, R. C. Weast \& S. M. Seiby, p. 532, Chem. Rubber Co., Cleveland, USA (1956).

31) G. Hägg: Z. phys. Chem., B29, 95 (1935).

32) R. W.G. Wyckoff: "Crystal Structures," Vol. 1, p. 290, John Wiley, New York (1963).

33) K. M. Towe \& W. F. Bradley: J. Colloid. Interface Sci., 24, 384 (1967).

34) K. Kudo, T. Shibata, G. Okamoto \& N. Sato: Corrosion Sci., 8, 809 (1968).

35) C. L. Foley, K. Kruger \& C. N. J. Bechtoldt: J. Electrochem. Soc., 114, 994 (1967).

36) B. Agius \& J. Siejka: J. Electrochem. Soc., 120, 1019 (1973). 